UDC 336.22

JEL H20, H21, H25, K34

DOI 10.31375/2226-1915-2020-3-146-159

\title{
PROBLEMATIC ASPECTS OF TAXATION OF INDIVIDUAL-ENTREPRENEURS ON THE EXAMPLE OF HOTEL BUSINESS
}

Larisa Krysyuk

CEcon, docent, docent of the Department of Entrepreneurship and Tourism

E-mail: krysyuklarisa@gmail.com

ORCID ID: http://orcid.org/0000-0002-3979-0842

Tatyana Chebanova

CEcon, docent, docent of the Department of Entrepreneurship and Tourism

E-mail: ilyusha182004@gmail.com

ORCID ID: http://orcid.org/0000-0002-5142-1185

Alexandra Balandina

student of «Entrepreneurship, trade and exchange activity» E-mail: balandinaaleksandra6@gmail.com

Evgeniya Burlaka

student of «Entrepreneurship, trade and exchange activity»

E-mail: eburlaka07@gmail.com

Odessa National Marine University, Odessa, Ukraine

Abstract. Small business is a social and economic phenomenon. Each of those who take part in it can find their place in this sector of the economy. The state, local authorities, economic partners and entrepreneurs receive positive results from the activities of small enterprises. The role and place of small enterprises in the national economy is better manifested in the functions performed by these enterprises. Small business makes a significant contribution to the formation of a competitive environment. There are several conflicts currently. The first is a conflict between individual entrepreneurs and individuals. The second is a conflict between individual entrepreneurs on a simplified taxation system and a common system. Their taxation and the taxation of others differ from each other, which raises a large number of questions and dissatisfaction.

The main purpose of the work is to analyse and identify problematic aspects of taxation of entrepreneurs in Ukraine using the example of the hotel business.

A simplified taxation system can be chosen by both individual entrepreneurs and legal entities. Since the general system is more complicated in its form of taxation (accounting and reporting), more and more entrepreneurs are conducting their activities in a simplified taxation system.

Hotels, like any other enterprises, can at their discretion choose a taxation system within the limits proposed by the current legislation.

Hotels can use a simplified or general taxation system. These two systems have advantages and disadvantages. Individual entrepreneurs choose the most convenient system for themselves. Basically, they work on a simplified system, and this gives rise to a number of contradictions. If we compare an individual who works for an employer and an individual entrepreneur with the same income, then an individual who works for an employer has a higher tax burden.

The article examined the simplified and general taxation systems. These systems have both advantages and disadvantages. Individual entrepreneurs choose the most convenient system for themselves, according to their activities. Choosing a simplified system, individual entrepreneurs have an advantage in choosing a group in which they will carry out activities. This allows you to regulate the amount of income, and subsequently the amount of taxes.

Keywords: taxation, taxes, legal entities, individual entrepreneurs, hotel business.

(C) Крисюк Л.М., Чебанова Т.Є., Баландіна О.Г., Бурлака С.О., 2020 
УДК 336.22

JEL H20, H21, H25, K34

DOI 10.31375/2226-1915-2020-3-146-159

\section{ПРОБЛЕМНІ АСПЕКТИ \\ ОПОДАТКУВАННЯ ФІЗИЧНИХ \\ ОСІБ-ПІДПРИЕМЦІВ НА ПРИКЛАДІ ГОТЕЛЬНОГО БІЗНЕСУ}

Л.М. Крисюк

к.е.н., доцент, доцент кафедри підприємництва та туризму

E-mail: krysyuklarisa@gmail.com

ORCID ID: http://orcid.org/0000-0002-3979-0842

T.Є. Чебанова

к.е.н., доцент, доцент кафедри підприємництва та туризму

E-mail: ilyusha182004@gmail.com

ORCID ID: http://orcid.org/0000-0002-5142-1185

О.Г. Баландіна, Є.О. Бурлака

студентки спеціальності «Підприємництво, торгівля та біржова діяльність»

Одеський національний морський університет, Одеса, Украӥна

Анотація. Малий бізнес є соиіально-економічним явищем. Кожен з тих, хто бере в ньому участь, може знайти своє місие в иьому секторі економіки. Система оподаткування підприємств малого бізнесу $і$ оподаткування інших підприємств відрізняється між собою, щуо викликає велику кількість питань $i$ невдоволень. В даний час існуе декілька конфліктів. Перший - ие конфлікт між фізичними особами-підприемцями та фізичними особами. Другий - це конфлікт між фізичними особами-підприсмиями на спрощеній системі оподаткування $i$ загальній системі.

Головною метою роботи є проведення ана лізу та виявлення проблемних аспектів оподатку вання підприємиів в Украӥні на прикладі готельного бізнесу.

Готелі, як $і$ будь-які інші підприємства можуть на свій розсуд вибрати систему оподаткування в межах запропонованих чинним законодавством. Якщо порівняти фізичну особу, щчо прачюе на роботодавия і фізичну особу-підприємия з однаковими доходами, то, фізична особа, яка працює на роботодавия, несе більш високе податкове навантаження.

У статті було розглянуто спрощену $i$ загальну систему оподаткування. Ці системи мають як переваги, так $і$ недоліки. Фізичні особи-підприємиі вибирають для себе найбільи зручну систему відповідно до своєї діяльності. Вибираючи спрощену систему, фізичні особи-підприємиі мають перевагу y вигляді вибору групи, на якій буде здійснювати діяльність. Це дозволяє регулювати величину доходів, а в подальшому - $i$ величину податків.

Ключові слова: оподаткування, податки, юридичні особи, фізичні особи-підприємиі, готельний бізнес.
УДК 336.22

JEL H20, H21, H25, K34

DOI 10.31375/2226-1915-2020-3-146-159

ПРОБЛЕМНЫЕ АСПЕКТЫ

НАЛОГООБЛОЖЕНИЯ ФИЗИЧЕСКИХ ЛИЦ-ПРЕДПРИНИМАТЕЛЕЙ

НА ПРИМЕРЕ ГОСТИНИЧНОГО БИЗНЕСА

Л.М. Крысюк

к.э.н., доцент, доцент кафедры предпринимательства и туризма E-mail: krysyuklarisa@gmail.com

ORCID ID: http://orcid.org/0000-0002-3979-0842

T.Е. Чебанова

к.э.н., доцент, доцент кафедры предпринимательства и туризма E-mail: ilyusha182004@gmail.com

ORCID ID: http://orcid.org/0000-0002-5142-1185

А.Г. Баландина, Е.О. Бурлака

студентки специальности «Предпринимательство, торговля и биржевая деятельность»

Одесский начиональный морской университет, Одесса, Украина

Аннотация. Мальй бизнес является сочиально-экономическим явлением. Каждый из тех, кто принимает в нем участие, может найти свое место в этом секторе экономики. В настоящее время существует несколько конфликтов. Первый это конфликт между физическими лицами-предпринимателями и физическими лицами. Второй это конфликт между физическими лицами-предпринимателями на упрощенной системе налогообложения и общей системе. Их система налогообложения и налогообложение других предприятий отличается между собой, что вызывает большое количество вопросов и недовольств.

Главной иелью работы является проведение анализа и выявления проблемных аспектов налогообложения предпринимателей в Украине на примере гостиничного бизнеса.

Отели, как и любые другие предприятия, могут по своему усмотрению выбрать систему налогообложения в пределах предложенных действуюшим законодательством. Гостиницы могут использовать упрощенную или общую системы налогообложения. Эти две системы имеют как преимушества, так и недостатки.

В статье были рассмотрены упрощенная и общая системы налогообложения. Эти системы имеют как преимущества, так и недостатки. Физические лица-предприниматели выбирают для себя наиболее удобную систему, согласно своей деятельности. Выбирая упрощенную систему, физические лииа-предприниматели имеют преимущество в виде выбора группы, на которой будет осуществлять деятельность. Это позволяет регулировать величину доходов, а в дальнейшем и величину нало208.

Ключевые слова: налогообложение, налоги, юридические лица, физические лица-предприниматели, гостиничный бизнес. 
Постановка проблеми. Одне із провідних місць у господарській діяльності країни належить малим підприємствам. Малий бізнес є соціально-економічним явищем. Кожен 3 тих, хто бере в ньому участь, може знайти своє місце у цьому секторі економіки. Від діяльності малих підприємств отримують позитивні результати не тільки самі підприємці, а й держава, місцева влада і економічні партнери. Держава - за рахунок збільшення ВВП, зростання кількості робочих місць у реальній економіці та зменшення соціальної напруги; місцева влада - податки та зайнятість; економічні партнери - гнучких та динамічних співучасників 3 низькими накладними витратами [1]. Роль і місце малих підприємств в національній економіці найкраще виявляється в виконаних ними функціях. Малий бізнес робить вагомий внесок у формування конкурентного середовища. Вони $\epsilon$ антимонопольними, саме тому встановлюють здорову конкуренцію на ринку, надають ринковій економіці гнучкості, швидко реагують на зміну кон'юнктури ринку, створюють нові робочі місця, пом'якшують соціальну напругу [2].

На даний час існує декілька конфліктів. Перший - конфлікт між фізичними особами-підприємцями та фізичними особами. Другий - конфлікт між фізичними особами-підприємцями на спрощеній системі оподаткування та загальній системі. Їхне оподаткування та оподаткування інших відрізняється між собою, що викликає велику кількість питань та невдоволень.

Огляд останніх досліджень та публікацій. Система стимулювання діяльності фізичних осіб-підприємців має включати в себе широкий спектр напрямків оптимізації і спрощення обліку, оподаткування і звітності для суб'єктів господарювання. На сьогоднішній день система оподаткування діяльності ФОП (фізичної особипідприємця) характеризується певною незахищеністю i має широке коло проблем. Необхідно зазначити, що увага науковців, економістів, політиків зосереджується на аналізі та дослідженні оподаткування фізичних осіб-підприємців. Система оподаткування діяльності фізичних осіб-підприємців формується на основі взаємодії ринкового й адміністративнорозподільчого механізмів. На сьогодні існуюча система оподаткування діяльності ФОП характеризується певною невизначеністю і має широке коло проблем. Ці питання розглядались у публікаціях таких дослідників як Коцупатрий М.M. [3], Ковач C.I. [3], Безверхий К.В. [3], Михальчинець Г.Т. [6], Головашевич О.О. [7], Філіппов В.Ю. [8], Мартиненко В.П. [13].

Завдання дослідження. Головною метою роботи $є$ проведення аналізу та виявлення проблемних аспектів оподаткування підприємців в Україні на прикладі готельного бізнесу.

Основний матеріал дослідження. Відповідно до законодавства України, існує дві системи оподаткування: загальна та спрощена система. Спрощену систему оподаткування можуть обирати, як фізичні особипідприємці, так і юридичні особи. Так як загальна система складніша за своєю формою оподаткування (за веденням обліку та складанням звітності), все більше підприємців веде свою діяльність на спрощеній системі опо- 
даткування [3]. Доля податкових надходжень від оподаткування фізичних осіб-підприємців $є$ вагомою. Особливого значення в процесі реалізації цього завдання набуває створення ефективного, гнучкого та дієвого механізму оподаткування фізичних осібпідприємців. Основним фінансовим інструментом, що регулює взаємовідносини підприємств 3 державою, $\epsilon$ оподаткування. Для розвитку малого підприємства держава надає ряд підтримок. На сьогоднішній день в най- більш розвинених країнах Заходу малі підприємництва становлять 70-90 \% від загальної кількості підприємств [6]. Станом на 1 лютого 2019 року в Україні перебуває 1778 тис. фізичних осіб-підприємців. 3 кожним роком кількість ФОПів зростає. Щодо України малі підприємства складають $14 \%$ від загальної кількості підприємств, а ФОПи - $73 \%$. Дані по кількості підприємств за 2017-2018 pр. наведено на рис. 1.

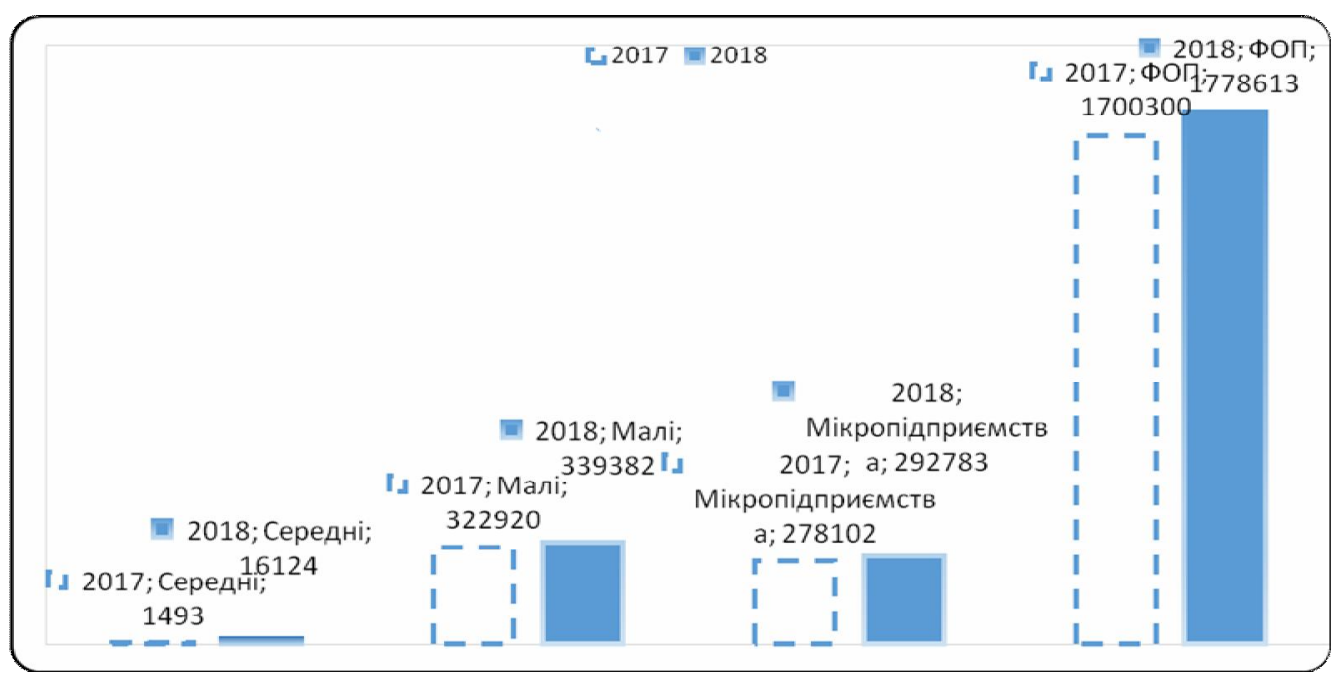

Рис. 1. Кількість підприємств за період з 2017 по 2018 рік, од.

Джерело: розроблено авторами на основі [4]

За 2018 рік було відкрито 272438 ФОП, а закрито - 178646. Найбільша кількість ФОП зареєстрована в Київській, Дніпропетровській, Харківській та Одеській області. Найменш активні - Волинська, Рівненська, Тернопільська та Кіровоградська область [8]. Рейтинг областей України за кількістю ФОП станом на 01.05.2019 рік наведений на рис. 2 .

Саме спеціальний податковий режим спрямований на стимулювання малого підприємництва, а його систе- ма припускає тільки один вид податку: єдиний податок, який сплачується до місцевого бюджету. Незалежно від цього підприємці платять єдиний соціальний внесок, до складу якого входить Пенсійний фонд України. Підприємці, які вже є пенсіонерами, цей податок не сплачують, оскільки вже отримують пенсію. Кількість фізичних-осіб підприємців, які перебувають на обліку в органах ДФС (Державна фіскальна служба) наведена на рис. 3 . 
DEVELOPMENT OF MANAGEMENT AND ENTREPRENEURSHIP METHODS

ON TRANSPORT, № 3 (72), 2020
РОЗВИТОК МЕТОДІВ УПРАВЛІННЯ ТА ГОСПОДАРЮВАННЯ НА ТРАНСПОРТІ, № 3 (72), 2020

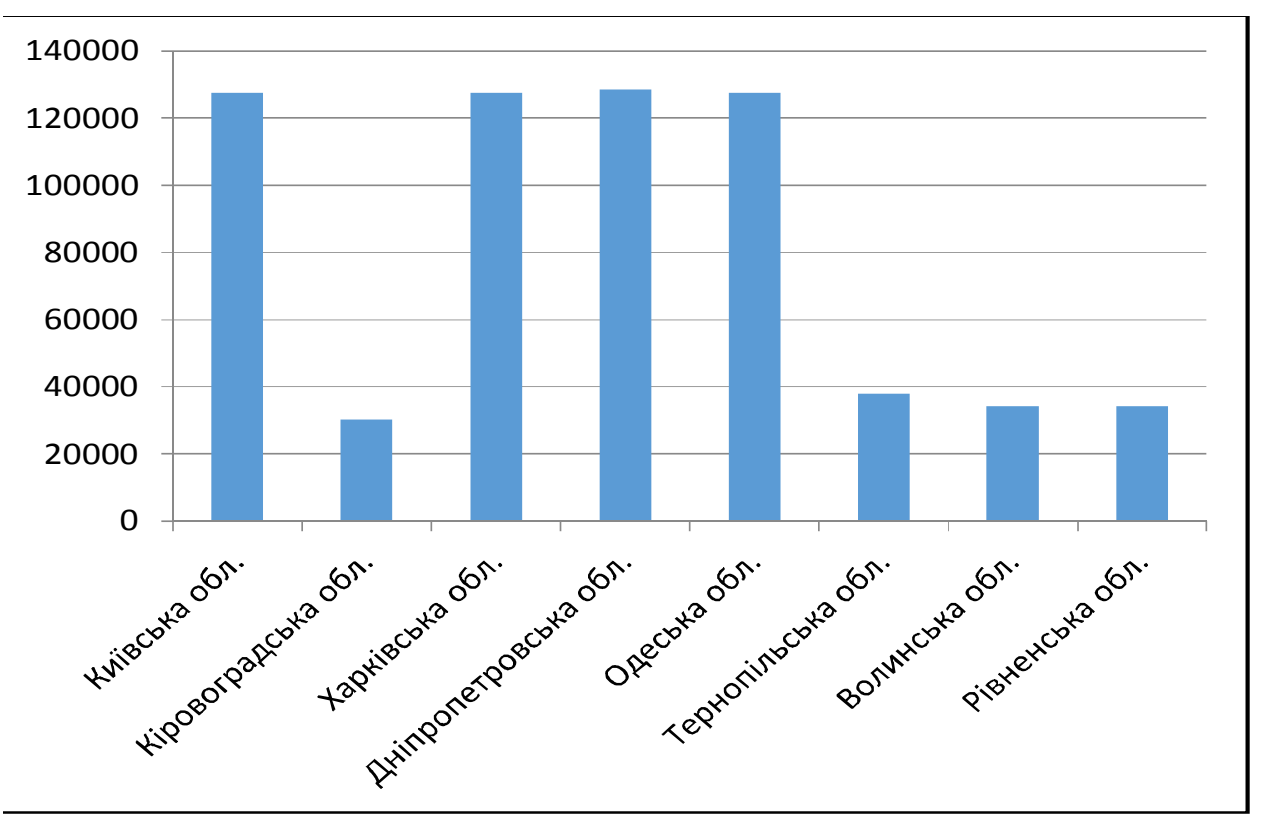

Рис. 2. Кількість фізичних осіб-підприємщів за областями, од.,01.05.2019

Джерело: розроблено авторами на основі [4; 10]

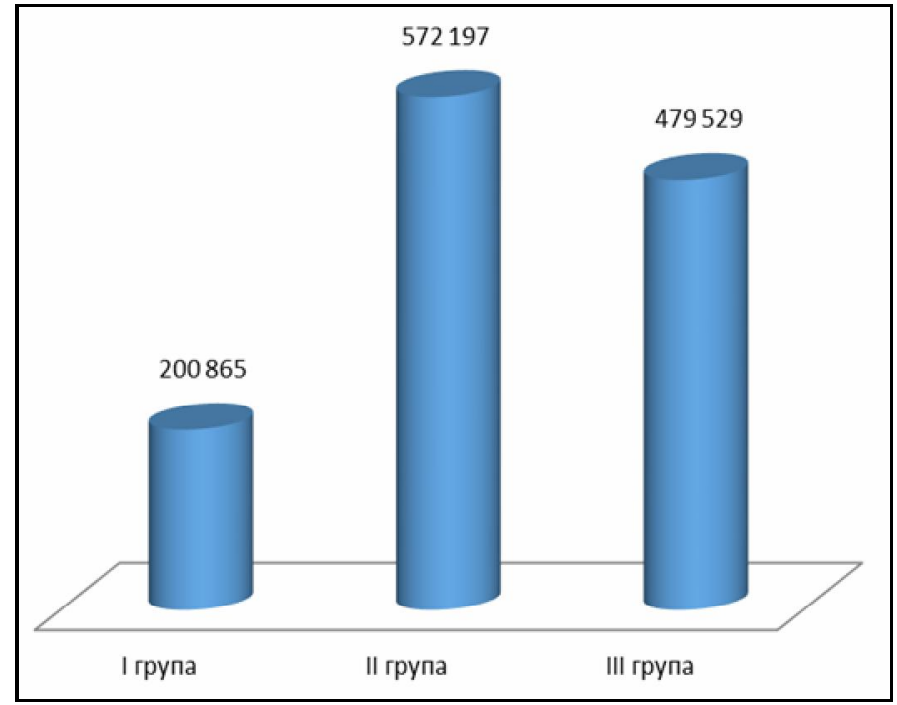

Рис. 3. Кількість фізичних-осіб підприємиів,

які перебувають на обліку в органах ДФС, од., станом на 01.01.2019

Джерело: розроблено авторами на основі [5] 
DEVELOPMENT OF MANAGEMENT
РОЗВИТОК МЕТОДІВ

УПРАВЛІННЯ ТА ГОСПОДАРЮВАННЯ

НА ТРАНСПОРТІ, № 3 (72), 2020
Виходячи 3 цього, ми бачимо, що значну частину складає ФОП II групи - 572197 од., потім III групи 479529 од., а I група має найменшу кількість і складає - 200865 од. Надходження коштів до бюджету по єдиному внеску наведено на рис. 4.

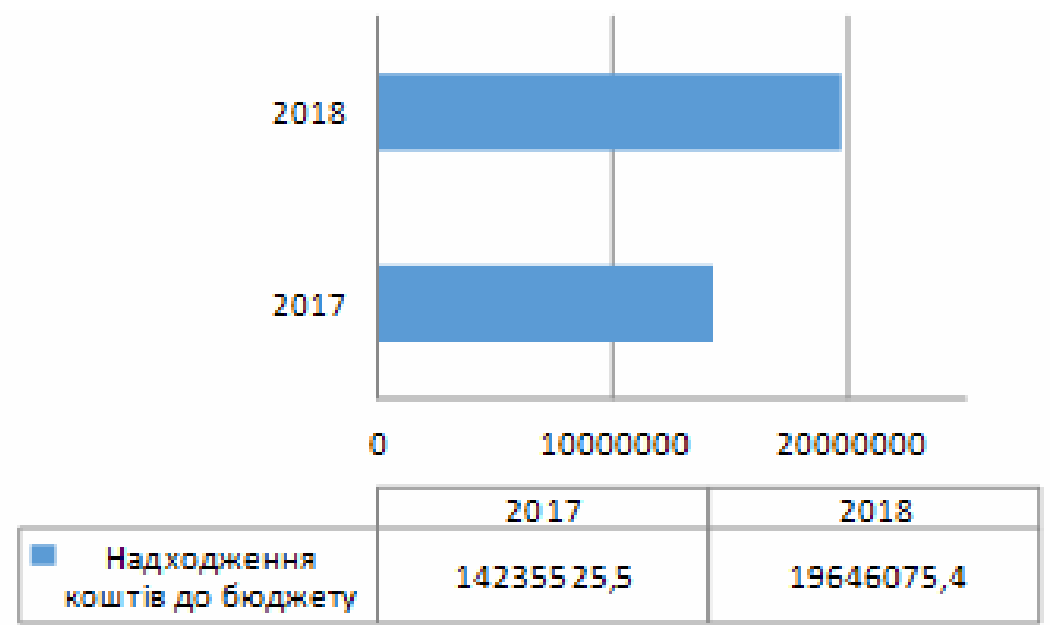

Рис. 4. Надходження коштів до бюджету по єдиному внеску, тис. грн.

Джерело: розроблено авторами на основі [10]

В 2018 році порівняно з 2017 роком різниця між надходженнями до бюджету склала 5410549,9 тис. грн., тобто збільшилася на $38 \%$.
На рис. 5 представлена динаміка зростання кількості ФОП по Україні впродовж досліджуваного періоду (01.05.2018-01.05.2019 рр.) по місяцям.

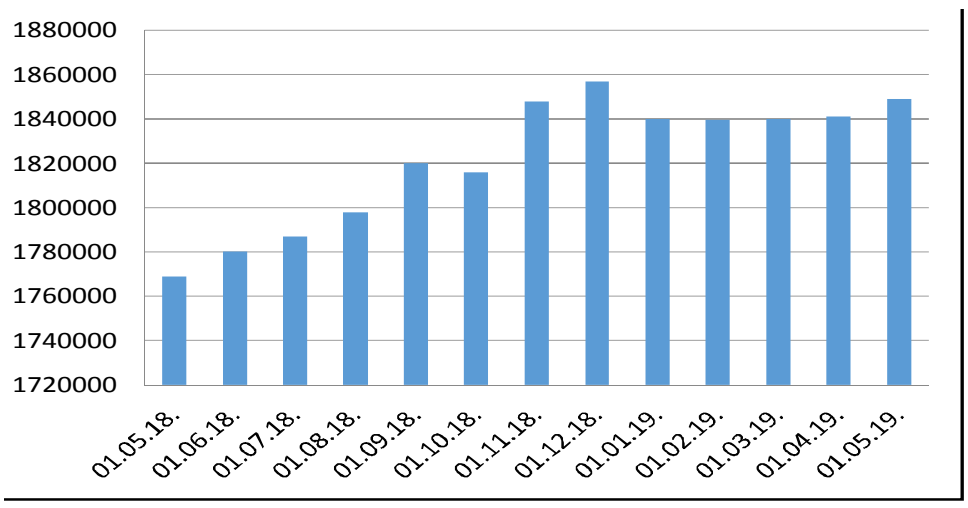

Рис. 5. Кількість створених ФОП по Україні за 2018-2019 рік, од.

Джерело: розроблено авторами на основі [4;10] 
Виходячи із наведених даних, представлених на рис. 5, можемо зробити висновок, що за перші кілька місяців була невелика підприємницька активність, але вже в кінці року вона значно зросла і в 2019 році динаміка кількості закритих та створених підприємств стабілізувалася.

01 січня 2017 року набув чинності Закон України «Про внесення змін до деяких законодавчих актів України», який вносить зміни до Закону України «Про збір на облік єдиного внеску на загальнообов'язкове державне соціальне страхування», що було причиною зменшення кількості фізичних осіб-підприємців у 2017 році. У 2018 році підприємці змогли адаптуватися під внесені зміни і через це відбувся невеликий, але помітний підйом підприємницької діяльності [11].

Так, за аналізований період 3 01.05.2018 р. до 01.05.2019 р. кількість ФОП збільшилася на 79399. Так, на початок аналізованого періоду в Україні було зареєстровано 1768953 ФОП, і вже на кінець - активних приватних підприємців нараховується вже 1848352.

Кількість ФОП, що припинили свою діяльність, за областями України наведено на рис. 6 (станом на 01.05.2019 року).

Так, за кількістю закритих ФОП з 01.05.2018 по 01.05.2019 року лідирують Дніпропетровська, Харківська, Київська та Одеська області.

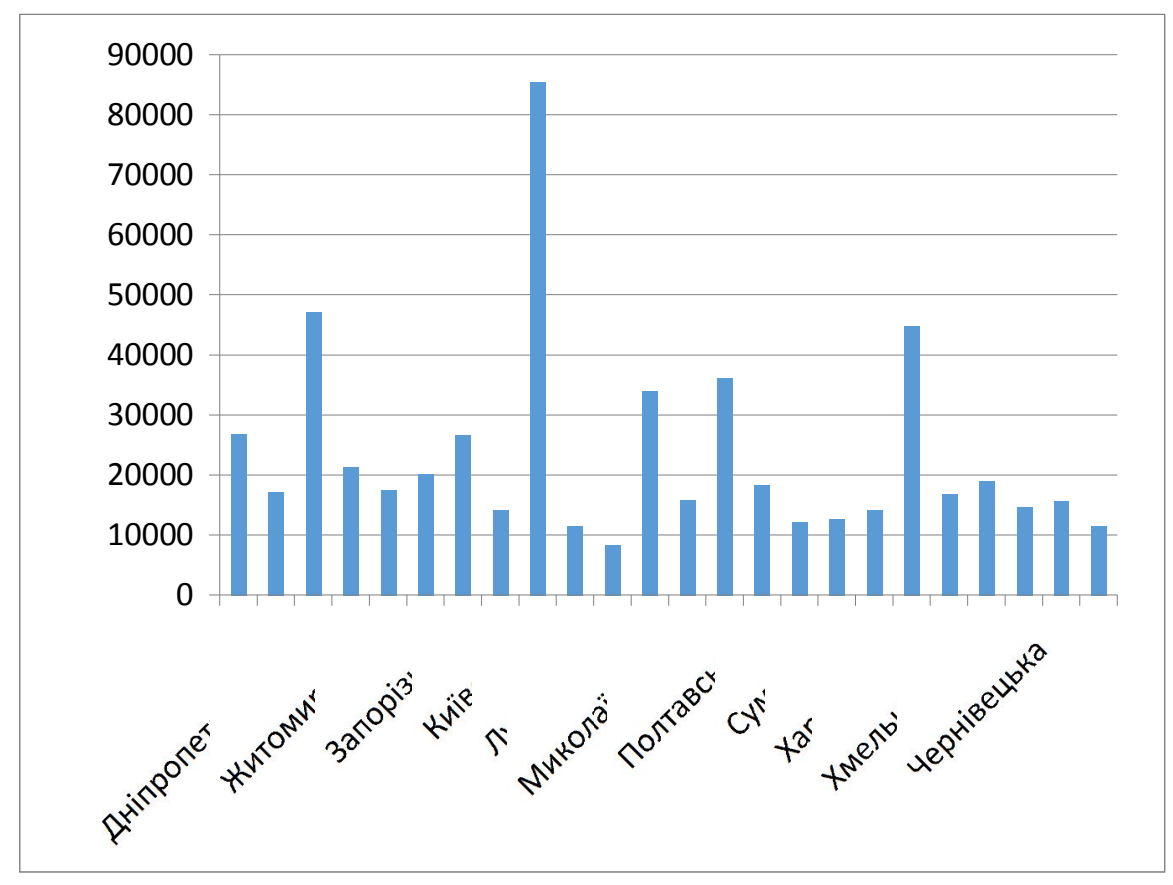

Рис. 6. Кількість ФОП, щуо припинили свою діяльність, за областями України, од.

Джерело: розроблено авторами на основі [4;10] 
DEVELOPMENT OF MANAGEMENT

AND ENTREPRENEURSHIP METHODS ON TRANSPORT, № 3 (72), 2020
РОЗВИТОК МЕТОДІВ

УПРАВЛІННЯ ТА ГОСПОДАРЮВАННЯ

НА ТРАНСПОРТІ, № 3 (72), 2020
Для визначення податкового навантаження, ми розрахували величину податків, які сплачують ФОП (I та II групи) та ФО (фізична особа). Станом на 01.01.2020 р. мінімальна заробітна платня складає 4723 грн., серед-ня заробітна платня - 10000 грн., прожитковий мінімум - 2102 грн. Ставка єдиного податку для ФОП
I групи складає $10 \%$ від прожиткового мінімуму, а для ФОП II групи $20 \%$ від мінімальної заробітної платні.

ФО сплачує податок на доходи фізичної особи, ставка податку складає $18 \%$ та воєнний збір, ставка податку складає - $1,5 \%$. Проведені розрахунки наведені в таблиці 1.

Таблиия 1

\section{Розрахунки по сплаті податків ФОП та ФО}

\begin{tabular}{|l|c|c|c|c|}
\hline \multicolumn{1}{|c|}{ Податки } & $\begin{array}{c}\text { ФО } \\
\text { (з мінімальною } \\
\text { заробітною } \\
\text { платнею) }\end{array}$ & $\begin{array}{c}\text { ФО } \\
\text { (з середньою } \\
\text { заробітною } \\
\text { платнею) }\end{array}$ & ФОП І група & ФОП ІІ група \\
\hline $\begin{array}{l}\text { Сдиний } \\
\text { податок (СП) }\end{array}$ & - & - & 210,20 & 944,60 \\
\hline $\begin{array}{l}\text { Сдиний } \\
\text { соціальний } \\
\text { внесок (ССВ) }\end{array}$ & - & - & 1039,06 & 1039,06 \\
\hline Воєнний збір & 70,85 & 150 & - & - \\
\hline $\begin{array}{l}\text { Податок } \\
\text { на доходи } \\
\text { фізичних осіб }\end{array}$ & 850,14 & 1800 & - & - \\
\hline Всього & 920,99 & 1950 & 1249,26 & 1983,66 \\
\hline
\end{tabular}

\section{Джерело: розроблено авторами на основі [12;14]}

Виходячи 3 розрахунків, той факт, що сума сплати податків ФОП (І група) складає $10 \%$ від прожиткового мінімуму, говорить нам про те, що їх оподаткування є послабленням податкового навантаження. Навіть те, що ФОП сплачує $С \mathrm{CB}$, в порівнянні з ФО, не надто збільшує надходження до бюджету від них. Це видно у співвідношенні з податковим тягарем на фонд оплати праці фізичної особи. Податкове навантаження нерівномірне між ФОП та ФО, оскільки при менших доходах ФО сплачує у 10 разів більше. Про те, що податковий тягар на фізичних осіб досить великий, свідчить ще те, що вони спла- чують непрямі податки в ціні товарів та послуг [13].

Розглянемо другий конфлікт між ФОП на загальній системі оподаткування та ФОП на спрощеній системі. Визначимо, чим відрізняються ці дві системи оподаткування.

1. База розрахунку суми податку. Для загальної системи податок вираховується від прибутку. Тобто ведеться облік і доходів і витрат, щоб порахувати прибуток і саме від прибутку і сплачується єдиний податок. На спрощеній системі для єдиного податку - це буде виручка від реалізації послуг, витрати до уваги не бе- 
DEVELOPMENT OF MANAGEMENT

AND ENTREPRENEURSHIP METHODS ON TRANSPORT, № 3 (72), 2020
РОЗВИТОК МЕТОДІВ

УПРАВЛІННЯ ТА ГОСПОДАРЮВАННЯ

НА ТРАНСПОРТІ, № 3 (72), 2020 руться. Прийшли гроші - сплачується податок.

2. Бартерні операції, взаємозаліки. На загальній системі допускаються бартери і взаємозаліки. На спрощеній системі оподаткування лише готівкова і безготівкова форми розрахунків.

3. Обмеження щодо кількості працівників. На загальній системі обмежень не має, а на спрощеній системі обмеження встановлюються в залежності від групи платника єдиного податку.

4. Максимальна річна сума виручки. На загальній системі оподаткування не має обмежень, а на спрощеній системі: I група 1000000 грн.; II група - 5000000 грн.; III група - 10000000 грн.

5. Які податки ФОП сплачує за себе? Загальна система: ПДФО $18 \%$, ССВ - $22 \%$, військовий збір $15 \%$. Спрощена система: єдиний податок - $5 \%$ від доходу або фіксована сума податку - 10 або $20 \%$ та єдиний соціальний внесок ( $\mathrm{CCB}$ ) за ставкою $22 \%$ від самостійно визначеної суми, але не менше мінімального розміру, тобто не менше $22 \%$ від мінімальної заробітної плати [16].

Порівнявши дві системи оподаткування, ми можемо зробити висновок, що однозначно кращої системи немає. Все залежить від того, який прибуток має підприємство. Спрощена система вигідна для того бізнесу, який $\epsilon$ високоприбутковим, i цей прибуток на постійній основі немає великих постійних витрат. Загальна ж система більш вигідна в абсолютно протилежній ситуації.

Розглянемо спрощену та загальну систему оподаткування в сфері готельних послуг. Готелі, як і будь- які інші підприємства, можуть на власний розсуд обрати систему оподаткування в межах запропонованих чинним законодавством. Вибираючи спрощену систему ФОП стають платниками єдиного податку другої або третьої групи, і сплачують або до $20 \%$ від мінімальної заробітної платні, або 3 \% від доходу (5\% для тих, хто не сплачує ПДВ). Перевагами спрощеної системи для готельного бізнесу є те, що ведеться спрощений облік, зменшується кількість податків, саме тому зникає необхідність стеження за змінами податкового законодавства. Також не менш важливим $є$ той факт, що підприємство самостійно вирішує, чи бути платником ПДВ. Проте є ряд недоліків: обмеження за кількістю працівників, річного обсягу доходу та способів оплати податку.

Якщо готель веде оподаткування на загальній системі, то до податку на прибуток підприємства, i єдиного соціального внеску додається військовий збір, податок на землю та туристичний збір (якщо встановлений місцевими органами влади). Перевагами є той момент, що не маючи прибутку або будучи збитковим, підприємство не буде сплачувати податок на прибуток. Головним недоліком системи є: введення складної звітності.

На даний момент часу в кожній галузі відбувається пошук нових шляхів і методів виробництва, здійснюється аналіз сучасного стану, окреслюються перспективи на майбутнє. Готельний бізнес теж не лишився осторонь. Особливо актуальним для України є розвиток готельного бізнесу, оскільки завдяки даній галузі бізнесу Україна може поліпшити соціально-економічну ситуацію. 
DEVELOPMENT OF MANAGEMENT

AND ENTREPRENEURSHIP METHODS

ON TRANSPORT, № 3 (72), 2020
РОЗВИТОК МЕТОДІВ

УПРАВЛІННЯ ТА ГОСПОДАРЮВАННЯ

НА ТРАНСПОРТІ, № 3 (72), 2020
В наш час застосування нових технологій [15] в веденні бізнесу дозволяє готельєрам підвищити ефективність свого господарства. Саме в цій сфері найбільш часто зустрічаються і ФОП, і юридичні особи.

За даними Держкомстату України на 2017 рік в сфері готельного бізнесу зареєстровано 4115 суб'єктів господарювання, 3 них 2064 із юридичним статусом $(50,2 \%)$ та 2051 фізичних осіб-підприємців (49,8 \%). В ході дослідження проведено аналіз загальної характеристики колективних засобів розміщення за 2017 рік [17]. Дані наведені в таблиці 2.

Таблиия 2

\section{Загальна характеристика готелів та аналогічних засобів розміщення}

\begin{tabular}{|l|c|c|}
\hline \multicolumn{1}{|c|}{$\begin{array}{c}\text { Кількість засобів розміщення, } \\
\text { усього }\end{array}$} & $\begin{array}{l}\text { Кількість колективних } \\
\text { засобів розміщення, од. }\end{array}$ & $\begin{array}{c}\text { Доходи від наданих } \\
\text { послуг, тис. грн. }\end{array}$ \\
\cline { 2 - 3 } $\begin{array}{l}\text { Готелі та аналогічні засоби } \\
\text { розміщення, усього }\end{array}$ & 4115 & 12683950,00 \\
\hline $\begin{array}{l}\text { 3 них: } \\
\text { Готелі }\end{array}$ & 2474 & 8629300,60 \\
\hline Мотелі & 1704 & 4966373,70 \\
\hline Хостели & 36 & 16114,80 \\
\hline Кемпінги & 12 & 3845,40 \\
\hline Агроготелі & - & 64048,20 \\
\hline Гуртожитки для приїжджих & 84 & 311257,00 \\
\hline $\begin{array}{l}\text { Туристичні бази, гірські притулки, } \\
\text { студентські літні табори, інші } \\
\text { місця для тимчасового розміщення }\end{array}$ & 501 & \\
\hline
\end{tabular}

Джерело: розроблено авторами на основі [18]

Виходячи 3 наведених даних в таблиці 2, ми можемо зробити висновок, що готельний бізнес насправді $\epsilon$ перспективною галуззю підприємництва. Встановлено, що найбільш прибутковими колективними засобами розміщення є готелі та аналогічні засоби розміщення, частка яких складає $60,1 \%$ від загальної кількості. Відповідно і прибуток від їх діяльності $є$ найбільшим і складає 8629 300,60 тис. грн.
В готельному бізнесі велика кількість як ФОП, так і юридичних осіб. Розглянемо їх співвідношення на рис. 7.

На рис. 7 видно, що в сфері готельного бізнесу переважають фізичні особи-підприємці. Як було вище сказано, це спричинено тим, що під час вибору системи оподаткування підприємець обирає легшу систему ведення документації, яка притаманна саме фізичній особі-підприємцю. 
DEVELOPMENT OF MANAGEMENT AND ENTREPRENEURSHIP METHODS ON TRANSPORT, № 3 (72), 2020
РОЗВИТОК МЕТОДІВ

УПРАВЛІННЯ ТА ГОСПОДАРЮВАННЯ

НА ТРАНСПОРТІ, № 3 (72), 2020

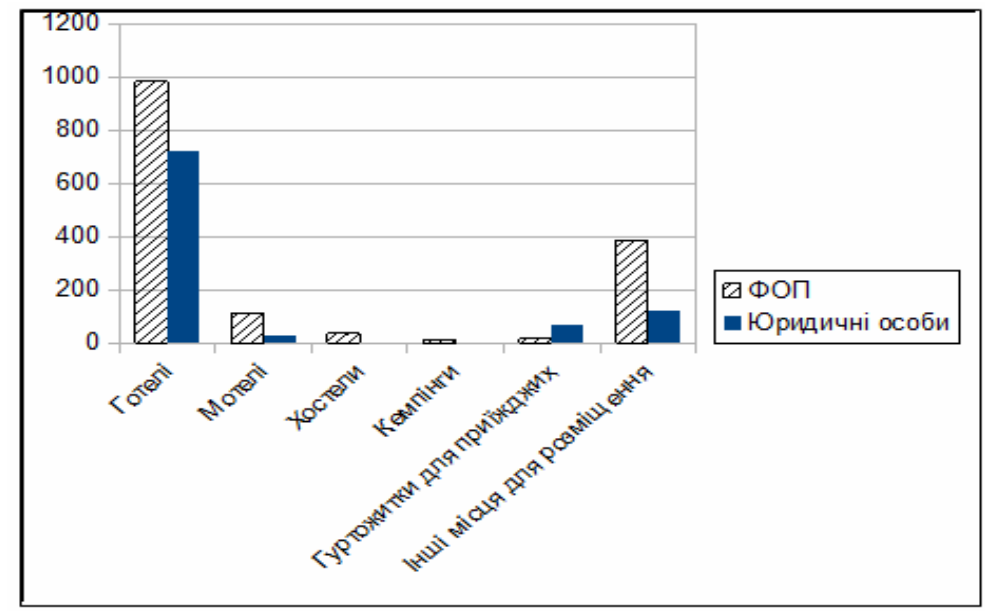

Рис. 7. Характеристика кількості готелів

та аналогічних засобів розміщення для ФОП, 2017 рік

Джерело: розроблено авторами на основі [18]

Проаналізуємо співвідношення кількості найманих та позаштатних працівників та доходи в розподілі на ФОП та юридичних осіб на рис. 8.

Виходячи 3 рис. 8 , ми можемо зробити висновок, що кількість най- маних працівників у ФОП в 11 разів менша, ніж у юридичних осіб, а доходи більші. Це спричинено тим, що вони сплачують менші податки, які пов'язанні 3 найманими працівниками.

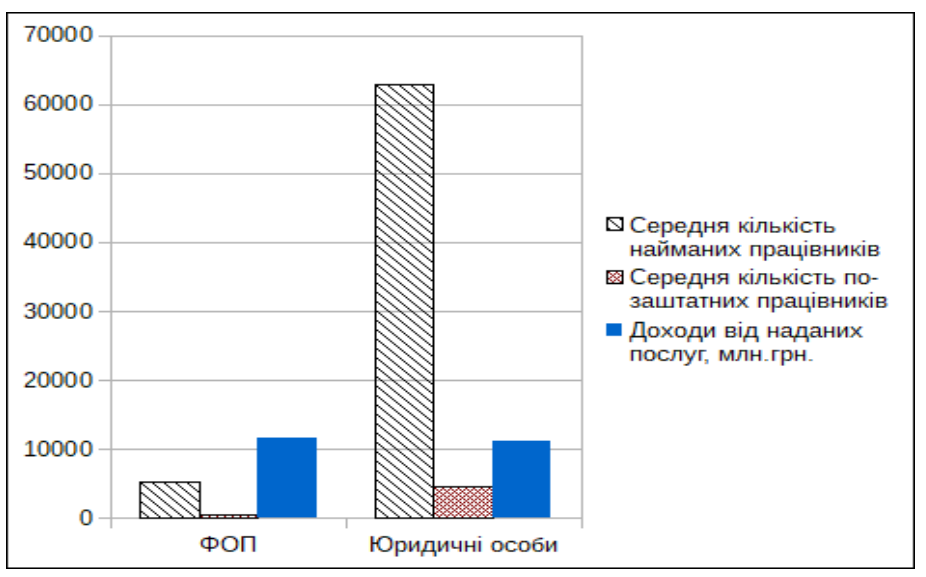

Рис. 8. Порівняння кількості найманих, позаштатних працівників та доходів ФОП і юридичних осіб, 2017 рік

Джерело: розроблено авторами на основі [18]

Висновки. У статті було розглянуто спрощену та загальну системи оподаткування, на якій можуть 156 перебувати ФОП. Ці дві системи 
мають як переваги, так і недоліки. Фізичні особи-підприємці обирають для себе найзручнішу систему відповідно до своєї діяльності. Обираючи спрощену систему, ФОП має перевагу у вигляді вибору групи, на якій буде здійснювати діяльність. Це дає змогу регулювати величину доходів, а в подальшому - i величину податків.

\section{СПИСОК ЛІТЕРАТУРИ}

1. Місие малого бізнесу в економіці краӥни. URL: https://m.pidruchniki. com/1797042060923/ekonomika/mistse_malogo_biznesu_ekonomitsi_krayini.

2. Малі підприємства: сутність та значення для розвитку економіки. URL: http://ru.osvita.ua/vnz/reports/econom_pidpr/21923/

3. Коиупатрий М.М., Ковач С.I., Безверхий К.В. Системи оподаткування діяльності фізичної особи-підприємия в Україні // Гроші, фінанси $i$ кредит. 2012. № 10. С. 183-194.

4. Офіційна сторінка Державного комітету статистики України URL: http://www.ukrstat.gov.ua.

5. Офіційна сторінка Державної фіскальної служби України URL: http:// www.ukrstat.gov.ua.

6. Михальчинецьь Г.Т. Оподаткування бізнесу як напрям розвитку підприсмництва в Украӥні // Молодий вчений. 2014. № 11. С.79-82.

7. Головамевич О.О. Фізична особа як платник податків // Актуальні питання науки фінансового права. 2010. С.237-266.

8. Філіппов В.Ю. Про регіональний розподіл трендів у сфері зайнятості в Одеському регіоні на 2018-2019 роки // Проект «Тривалий економічний підйом для миру». 2019. С.5-7.

9. Платформа ефективного регулювання URL: https://regulation.gov.ua

10. Офіційний сайт Головного управління статистики в Одеській області URL: http://www.od.ukrstat.gov.ua

11. Про збір на облік єдиного внеску на загальнообов'язкове державне соціальне страхування: Закон України від 01.01.2017 № 2464-VI URL: https:// zakon.rada.gov.ua/laws/main/2464-17.

12. Офіиійний сайт Міністерства Украӥни. URL: https://index.minfin.com.ua/ ua/labour/wagemin

13. Мартиненко В.П. Основні напрямки розвитку оподаткування доходів фізичних осіб // Формування ринкових відносин в Украӥні: 3б. наук. праць. Bun. 5 (84). 2008.C. 70-74.

14. Бізнес Peєcmpamop URL: http://xn----7sbihqb7baaldln2dyh.com.ua/ua.html

15. Oleksandr Kanifolskyi. New energy wave criterion (EWC) and possible areas of its application // International Journal on Interactive Design and Manufacturing (IJIDeM). Springer. 2019. № 14(2). P.719-725, URL: https:// doi.org/10.1007/s12008-019-00609-z (індексачія в Sсориs)

16. Про особливості здійснення державного нагляду (контролю) у сфері господарської діяльності щчодо фізичних осіб-підприємџів та юридичних осіб, які застосовують спрощену систему оподаткування, обліку та звіт- 
ності: Закон України від 23.02.2012 № 4448- VI URL: https://zakon. rada.gov.ua/laws/main/4448-17

17. Особливості оподаткування суб'єктів готельного бізнесу в Україні URL: Колективні засоби розмімування в Україні у 2017 роиі // Статистичний збірник. 2018. С.13, 24, 25.

18. Колективні засоби розміщування в Україні у 2017 роичі // Статистичний збірник. 2018. С.13, 24, 25.

\section{REFERENCES}

1. Mistse maloho biznesu v ekonomitsi krainy [The place of small business in the economy countries]. Retrieved from https://m.pidruchniki.com/ 1797042060923/ekonomika/mistse_malogo_biznesu_ekonomitsi_krayini. [in Ukrainian].

2. Mali pidpryiemstva: sutnist ta znachennia dlia rozvytku ekonomiky [Small enterprises: essence and significance for economic developmen]. Retrieved from http://ru.osvita.ua/vnz/reports/econom_pidpr/21923. [in Ukrainian].

3. Kotsupatryi, M.M., Kovach, S.I. \& Bezverkhyi, K.V. (2012). Systemy opodatkuvannia diialnosti fizychnoi osoby-pidpryiemtsia v Ukraini [Taxation systems for the activities of a natural person-entrepreneur in Ukraine]. Hroshi, finansy i kredyt, №10,183-194 [in Ukrainian].

4. Ofitsiina storinka Derzhavnoho komitetu statystyky Ukrainy [Official page of the State Statistics Committee of Ukraine]. Retrieved from http://www.ukrstat.gov.ua.

5. Ofitsiina storinka Derzhavnoi fiskalnoi sluzhby Ukrainy [Official page of the State Fiscal Service of Ukraine]. Retrieved from http://www.ukrstat.gov.ua

6. Mykhalchynets H.T. (2014). Opodatkuvannia biznesu yak napriam rozvytku pidpryiemnytstva $v$ Ukraini [Business taxation as a direction of business development in Ukraine] Molodyi vchenyi. № 11. p.79-82.

7. Holovashevych, O.O. (2010). Fizychna osoba yak platnyk podatkiv [Individual as a taxpayer] Aktualni pytannia nauky finansovoho prava. p.237-266.

8. Filippov, V.Iu. (2019). Pro rehionalnyi rozpodil trendiv u sferi zainiatosti v Odeskomu rehioni na 2018-2019 roky [On the regional distribution of trends in the field of employment in the Odessa region for 2018-2019]. Proekt «Tryvalyi ekonomichnyi pidiom dlia myru». p.5-7. [in Ukrainian].

9. Platforma efektyvnoho rehuliuvannia [Platform for effective regulation]. Retrieved from https://regulation.gov.ua. [in Ukrainian].

10. Ofitsiinyi sait Holovnoho upravlinnia statystyky v Odeskii oblasti [Official site of the Main Department of Statistics in Odessa region]. Retrieved from http://www.od.ukrstat.gov.ua. [in Ukrainian].

11. Pro zbir na oblik yedynoho vnesku na zahalnooboviazkove derzhavne sotsialne strakhuvannia: Zakon Ukrainy vid 01.01.2017 №2464-VI [On the collection of a single contribution to the obligatory state social insurance: 
Law of Ukraine of 01.01.2017 642464-VI]. Retrieved from https://zakon.rada. gov.ua/laws/main/2464-17.

12. OfItsIyniy sayt Ministerstva Ukrayini [Official site of the Ministry of Ukraine]. Retrieved from https://index.minfin.com.ua/ua/labour/wagemin. [in Ukrainian].

13. Martynenko, V.P. (2008). Osnovni napriamky rozvytku opodatkuvannia dokhodiv fizychnykh osib [The main directions of development of personal income taxation] Formuvannia rynkovykh vidnosyn v Ukraini: zbirnyk naukovykh prats. K.: NDEI Ministerstva ekonomiky Ukrainy, Vyp. 5 (84). S. 70-74. [in Ukrainian].

14. Biznes Reiestrator [Business Registrar]. Retrieved from http://xn----7sbihqb7 baaldln2dyh.com.ua/ua.html

15. Oleksandr Kanifolskyi (2019). New energy wave criterion (EWC) and possible areas of its application // International Journal on Interactive Design and Manufacturing (IJIDeM). Springer, 14(2), 719-725, https://doi.org/ 10.1007/s12008-019-00609-z

16. Pro osoblyvosti zdiisnennia derzhavnoho nahliadu(kontroliu) u sferi hospodarskoi diialnosti shchodo fizychnykh osib- pidpryiemtsiv ta yurydychnykh osib, yaki zastosovuiut sproshchenu systemu opodatkuvannia, obliku ta zvitnosti: Zakon Ukrainy vid 23.02.2012 № 4448-VI. [On the peculiarities of state supervision (control) in the field of economic activity in relation to natural persons-entrepreneurs and legal entities that apply the simplified system of taxation, accounting and reporting: Law of Ukraine of 23.02.2012 № 4448-VI]. Retrieved from https://zakon.rada.gov.ua/laws/main/4448-17 [in Ukrainian].

17. Osoblyvosti opodatkuvannia subiektiv hotelnoho biznesu v Ukraini [Features of taxation of hotel business entities in Ukraine]. Retrieved from http://xn---7sbihqb7baaldln2dyh.com.ua/ua.html[in Ukrainian].

18. Kolektyvni zasoby rozmishchuvannia v Ukraini u 2017 rotsi [Collective accommodation facilities in Ukraine in 2017]. Statystychnyi zbirnyk. 2018 p.13,24,25. [in Ukrainian].

Стаття надійшла до редакиії 17.09.2020

Посилання на статтю: Крисюк Л.М., Чебанова Т.С., Баландіна О.Г., Бурлака Є.О. Проблемні аспекти оподаткування фізичних осіб-підприємців на прикладі готельного бізнесу // Розвиток методів управління та господарювання на транспорті: Зб. наук. праць, 2020. № 3 (72). C. 146-159. DOI 10.31375/2226-1915-2020-3-146-159.

Article received 17.09.2020

Reference a JournalArtic: Krysyuk, Larisa, Chebanova, Tatyana, Balandina, Alexandra \& Burlaka, Evgeniya (2020). Problematic aspects of taxation of individualentrepreneurs on the example of hotel business. Development of management and entrepreneurship methods on transport, 3 (72), 146-159. DOI 10.31375/2226-1915-2020-3146-159. 